\title{
Weed interference periods in sesame crop
}

\section{Períodos de interferência de plantas daninhas na cultura do gergelim}

\author{
Hamurábi Anizio Lins ${ }^{1 *} \mathbb{D}$, Matheus de Freitas Souza' ${ }^{1}$, José Ricardo Tavares de Albuquerque ${ }^{1} \mathbb{D}$, \\ Manoel Galdino dos Santos ${ }^{1} \mathbb{D}$, Aurélio Paes Barros Júnior ${ }^{1}(\mathbb{D})$, Daniel Valadão Silva ${ }^{1}(\mathbb{D})$
}

\author{
'Universidade Federal Rural do Semi-Árido/UFERSA, Mossoró, RN, Brasil \\ *Corresponding author: hamurabi_a_@hotmail.com \\ Received in January 15, 2019 and approved in June 10, 2019
}

\begin{abstract}
The sesame crop (Sesamum indicum L.) is sensitive to competition with weeds because of its low competitiveness that is directly linked to its slow initial growth. The control of weeds in the crop is an essential practice to ensure the high productivity of this oilseed. Therefore, to define the critical period of interference prevention is important to ensure efficiency and low control costs. Factors such as cultivar, environmental conditions, and cultivation system may alter the critical weed interference prevention period (CPWC). Therefore, the objective of this work was to determine the critical weed interference prevention period in two sesame cultivars. The critical weed interference prevention period for sesame cultivars, BRS Seda and CNPA G2, was defined in two years (2016 and 2017). Log-logistic regression of four parameters was used to determine the critical weed interference prevention period. The cultivar CNPA G2 was more competitive compared to the cultivar BRS Seda. The CPWC for BRS Seda was on average 67 and 52 days, whereas for CNPA G2 was 52 and 34 days, considering respectively, a loss of 5 and $10 \%$. Weed control for BRS Seda and CNPA G2 should begin respectively between 12 and 15, and 17 and 20 days, considering a loss of 5 and $10 \%$.
\end{abstract}

Index terms: Competition; leaf area; plant height; productivity; oilseeds.

\begin{abstract}
RESUMO
A cultura do gergelim (Sesamum indicum L.) é sensível a competição com plantas daninhas devido a sua baixa competitividade que está diretamente ligada ao seu crescimento inicial lento. O controle de plantas daninhas na cultura é prática fundamental para assegurar a alta produtividade dessa oleaginosa. Nesse sentido, é importante definir o período crítico de prevenção a interferência para alcançar eficiência e baixo custo no controle. Os fatores como cultivar, condições ambientais e sistema de cultivo podem alterar o período crítico de prevenção à interferência de plantas daninhas (PCPI). Portanto, o objetivo deste trabalho foi determinar o período crítico de prevenção de interferência de plantas daninhas em duas cultivares de gergelim. O período crítico de prevenção de interferência de plantas daninhas para os cultivares de gergelim, BRS Seda e CNPA G2, foi definido em dois anos (2016 e 2017). Regressão log-logística de quatro parâmetros foi usada para determinar o período crítico de prevenção de interferência de plantas daninhas. A cultivar CNPA G2 foi mais competitiva em relação à cultivar BRS Seda. O PCPI para BRS Seda é em média 67 dias e 52 dias, enquanto para o CNPA G2 é de 52 dias e 34 dias, considerando respectivamente, uma perda de 5 e 10\%. O controle de plantas daninhas para BRS Seda e CNPA G2 deve iniciar respectivamente entre $12^{\circ}$ e $15^{\circ} \mathrm{dia}$, e $17^{\circ}$ e $20^{\circ} \mathrm{dia}$, considerando uma perda de 5 e $10 \%$.
\end{abstract}

Termos para indexação: Competição; área foliar; altura de planta; produtividade; oleaginosas.

\section{INTRODUCTION}

Among factors that reduce the sesame yield, the competition with weeds has considerable importance. The low competitiveness of this crop with weeds is directly linked to its slow initial growth (Mane et al., 2017). When weed control is not adopted, especially at initial periods, the sesame yield may be reduced by up to $75 \%$ (Bhadauria; Arora; Yadav, 2012).

The critical period for weed control (CPWC) should be defined to ensure the control efficiency and high yield (Swanton; Nkoa; Blackshaw, 2015). However, CPWC varies according to the cultivar, weed community, management system, and environmental conditions (Furtado et al., 2012). These factors together define the period which the crop cannot coexist with weeds, and therefore mechanical, physical, and chemical controls should be adopted (Chauhan; Mahajan, 2014).

Studies that evaluate the effect of factors that alter CPWC are necessary to estimate when weeds should be controlled. Several studies have already been carried out in 
different regions, systems, and environmental conditions to determine CPWC (Mahgoub; Omer; Elamin, 2014; Bahador; Moosavi, 2015; Zarghani et al., 2017). In addition to the environmental and cultivation conditions, the higher competitive capacity of cultivars can reduce CPWC, so investing those with higher growth rates and vigor may be an alternative to increase crop control and reduce the use of other control methods (Singh; Bhullar; Chauhan, 2014).

Sesame cultivars may have different morphological and physiological characteristics, such as initial growth rate and potential to close the canopy, so it was hypothesized that sesame cultivars have different values for CPWC. In this sense, the objective of this work was to determine the critical weed interference prevention period in two sesame cultivars.

\section{MATERIAL AND METHODS}

\section{Site description}

The experiments were conducted at the experimental farm Rafael Fernandes, belonging to the Universidade Federal Rural do Semi-Árido (5 $5^{\circ}$ ' $37^{\prime \prime} \mathrm{S}$ and $37^{\circ} 23^{\prime}$ $50^{\prime \prime} \mathrm{W}$ Gr), altitude approximately $72 \mathrm{~m}$, and the climate according to Thornthwaite is classified as DdAa' (Carmo Filho; Espínola Sobrinho; Maia Neto, 1991). The average precipitation is $750 \mathrm{~mm}$ year ${ }^{-1}$ and annual evaporation of $2000 \mathrm{~mm}$. Meteorological data during the period of the experiments were collected (Figure 1).

The soil is classified as Abrupt Eutrophic RedYellow Latosol, sandy texture (Embrapa, 2018). Soil preparation was carried out by plowing and harvesting. Fertilization was performed according to crop demand (Cavalcanti, 2008) and based on soil analysis (Table 1).
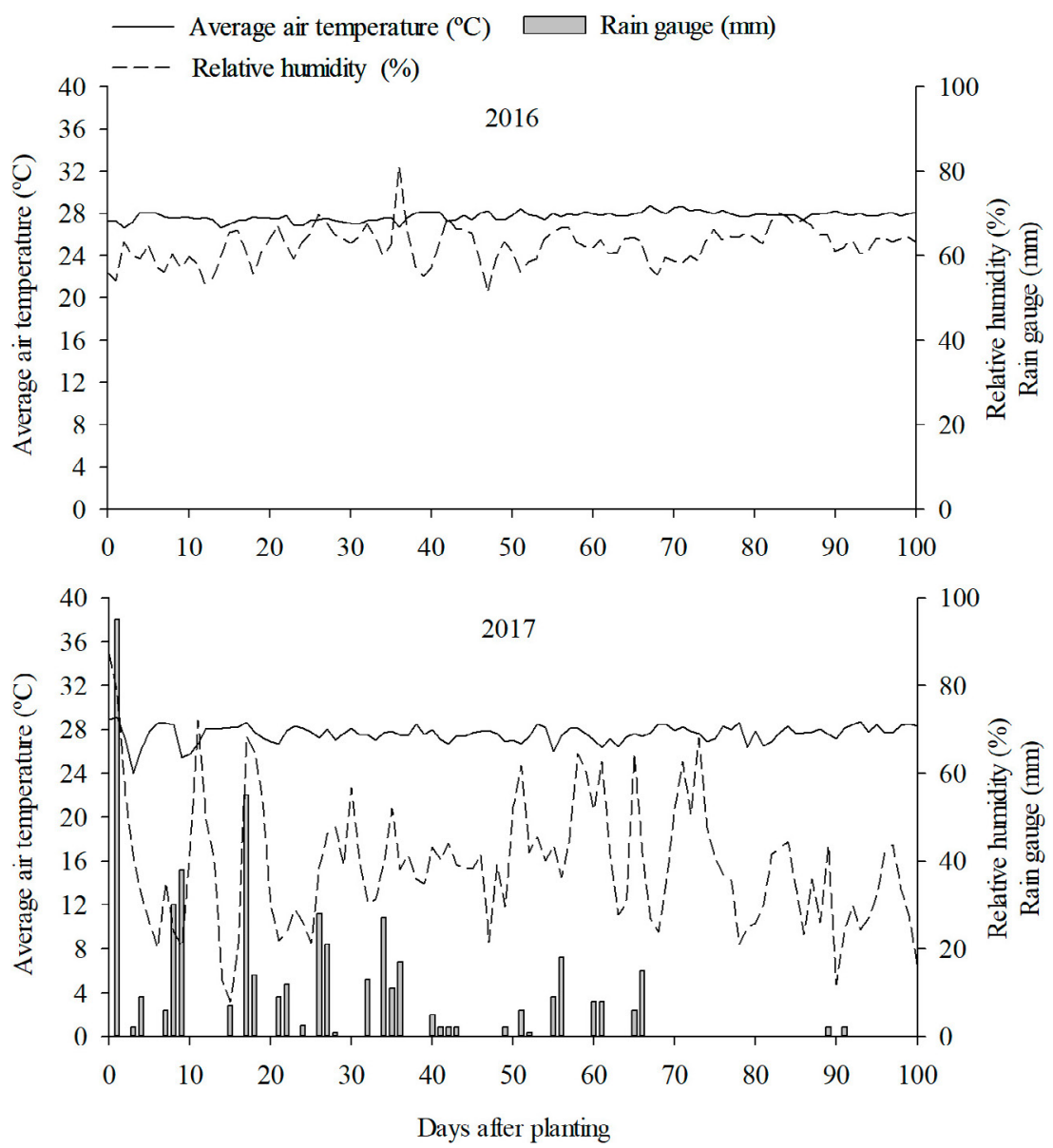

Figure 1: Mean values of instantaneous temperatures $\left({ }^{\circ} \mathrm{C}\right)$, maximum and minimum air, relative humidity (\%), and rainfall $(\mathrm{mm})$ in the two agricultural sesame crops. Source: INMET Automatic Weather Station, and rain gauge installed at the Experimental Farm. 
Table 1: Chemical characterization of the soil of the sesame crop areas.

\begin{tabular}{cccccccccc}
\hline Year & $\mathrm{N}$ & $\mathrm{MO}$ & $\mathrm{K}$ & $\mathrm{P}$ & $\mathrm{Na}$ & $\mathrm{Ca}$ & $\mathrm{Mg}$ & $\mathrm{pH}$ & $\mathrm{EC}$ \\
\hline & $\mathrm{g} \mathrm{kg}^{-1}$ & $\mathrm{~g} \mathrm{kg-1}$ & \multicolumn{2}{c}{$------\mathrm{mg} \mathrm{dm}^{-3}----^{--}$} & $---\mathrm{cmol}_{\mathrm{c}} \mathrm{dm}^{-3}---$ & & $\mathrm{ds} \mathrm{m}^{-1}$ \\
\hline 2016 & 0.14 & 7.23 & 52.01 & 4.47 & 8.1 & 2.10 & 0.55 & 6.50 & 0.585 \\
2017 & 0.42 & 12.78 & 58.8 & 3.0 & 4.8 & 1.00 & 1.80 & 5.63 & 0.747 \\
\hline
\end{tabular}

$\mathrm{N}=$ nitrogen; $\mathrm{MO}=$ organic matter; $\mathrm{K}=$ potassium; $\mathrm{P}=$ phosphorus; $\mathrm{Na}=$ sodium; $\mathrm{Ca}=$ calcium; $\mathrm{Mg}=\mathrm{magnesium} ; \mathrm{pH}=$ ionic hydrogen potential; $E C=$ electrical conductivity.

Fertilization before planting was carried out with $80 \mathrm{~kg} \mathrm{P}_{2} \mathrm{O}_{5}$ ha $^{-1}$, supply as mono-ammonium phosphate. Others two fertilization, $25 \mathrm{~kg} \mathrm{~N} \mathrm{ha}^{-1}$ and $60 \mathrm{~kg} \mathrm{~K}_{2} \mathrm{O} \mathrm{ha}^{-1}$, supply respectively as urea and potassium chloride, were applied via fertirrigation, with the aid of a bypass tank. This fertilization was used for both years. Phytosanitary control of pests and diseases were carried out according to the technical recommendations for the crop (Beltrão et al., 2013).

\section{Experimental design}

Two experiments were conducted to determine the CPWC of each sesame cultivar (CNPA G2 and BRS Seda). Both experiments were conducted over two years (2016 and 2017). The experiments were conducted in a randomized block design (RCBD) with three replicates. The treatments were constituted by six control periods and six coexistent periods between culture and weeds. The beginning of CPWC was obtained in treatments with weed control initialing at 10, 20, 30, 40, 50, and 100 Days After Emergence (DAE). The end of CPWC was determined by the treatments with weed control during 10, 20, 30, 40, 50, and 100 DAE.

Seeds were planted at spacing $0.30 \mathrm{~m} \times 0.60 \mathrm{~m}$, directly at $2 \mathrm{~cm}$ depth, placing 8 to 10 seeds per hole. Ten days after emergence, the roguing was carried out, leaving only two plants per hole. The dimension of the experimental plot was $3 \mathrm{~m} \times 2.4 \mathrm{~m}$, totaling an area of $7.2 \mathrm{~m}^{2}$ per plot.

The irrigation system used was drip irrigation. One drip tape was placed in each planting row. The spacing between drippers was $0.30 \mathrm{~m}$. Irrigations were performed daily according to the evapotranspiration of the crop (ETc) and coefficient of the crop $(\mathrm{Kc})$ in each stage of sesame development (Amaral; Silva, 2008).

\section{Data collection}

At the end of each coexistence period, the weeds present were collected in sample areas of $0.25 \mathrm{~m}^{2}$. After this procedure, the plants of each plot were counted, identified, packed in paper bags, and dried in a forced air circulation oven for 72 hours at $65^{\circ} \mathrm{C}$ to determine the dry matter. The densities were calculated from the total number of individuals per species divided by the total area. Density and dry matter of the weed community were extrapolated, respectively, to plants $\mathrm{m}^{-2}$ and $\mathrm{g} \mathrm{m}^{-2}$.

Ten harvested plants in the two middle rows were used to measure the height, from the base to the apical meristem $(\mathrm{cm})$ and leaf area $\left(\mathrm{cm}^{2}\right)$ of sesame cultivars at $10,20,30,40,50$, and $100 \mathrm{DAE}$ in the treatments with weed interference. The leaf area was obtained using a formula $\mathrm{AF}=\mathrm{C} \times \mathrm{L} \times \mathrm{f}$; where $\mathrm{C}=$ leaf length $(\mathrm{cm}), \mathrm{L}$ $=$ leaf width $(\mathrm{cm}), \mathrm{f}=$ correction factor $(0.7)$ (Silva et al. 2002). The harvest of sesame cultivars in 2016 and 2017 was performed $100 \mathrm{DAE}$ when the sesame plants showed yellow basal capsules. The capsules of ten plants harvested at 100 DAE were used to estimate the yield of cultivars. The capsules were dried in the sun for 30 days, and the grains were removed to estimate the yield $\left(\mathrm{kg} \mathrm{ha}^{-1}\right)$ at a humidity of $6 \%$.

\section{Statistical analysis}

The data for weed density and dry matter were presented and compared descriptively. The mean and confidence interval for plant height and leaf area were calculated and shown in graphs. The relative yield (\% of weed-free) were calculated and submitted to regression analysis (Knezevic; Streibig; Ritz, 2007). In this model log-logistic, y represents the relative productivity; $\mathrm{x}$ the days after the emergency; $A, B, c$, and EC50 are parameters of the equation (Equation 1). Losses of 5 and $10 \%$ were established to determine the CPWC of the cultivars.

$y=A+(B-A) /\left(1+\left(\frac{x}{E C 50}\right)^{-C}\right.$

SigmaPlot $12.0^{\circledR}$ software was used for regression analysis and construction of graphs. 


\section{RESULTS AND DISCUSSION}

\section{Weeds density and dry matter}

Weeds species in the plots within competition during all the sesame cycle in 2016 and 2017 were: Mimosa pudica, Mollugo verticillata, Blainvillea lanceolata, Portulaca oleracea, Sida spinosa, Aeschynomene rudis, Cyperus rotundus, Ipomoea triloba, Macroptilium atropurpureum, Senna alata, Commelina Benghalensis and Cynodon dactylon (Table 2 and Figure 2).

Table 2: Weed density in the study areas for each cultivar in 2016 and 2017.

\begin{tabular}{|c|c|c|c|}
\hline \multirow[b]{2}{*}{ Grow crops } & \multirow[b]{2}{*}{ Species of weeds present } & \multicolumn{2}{|c|}{$\begin{array}{c}\text { Density } \\
\text { (plants } \mathrm{m}^{-2} \text { ) }\end{array}$} \\
\hline & & 2016 & 2017 \\
\hline \multirow[t]{10}{*}{ BRS Seda } & Mimosa pudica & 8 & 21 \\
\hline & Mollugo verticillata & 13 & 13 \\
\hline & Blainvillea lanceolate & 5 & 19 \\
\hline & Portulaca oleracea & 3 & 3 \\
\hline & Sida spinosa & 4 & 4 \\
\hline & Aeschynomene rudis & - & 12 \\
\hline & Ipomoea triloba & - & 8 \\
\hline & Macroptilium atropurpureum & 1 & - \\
\hline & Senna alata & 3 & 3 \\
\hline & Commelina Benghalensis & - & 21 \\
\hline Total & & 37 & 104 \\
\hline \multirow{10}{*}{ CNPA G2 } & Mimosa pudica & 1 & 1 \\
\hline & Mollugo verticillata & 5 & 5 \\
\hline & Blainvillea lanceolate & 5 & - \\
\hline & Portulaca oleracea & 3 & 3 \\
\hline & Aeschynomene rudis & 1 & 1 \\
\hline & Cyperus rotundus & 5 & 5 \\
\hline & Ipomoea triloba & - & 11 \\
\hline & Macroptilium atropurpureum & - & 11 \\
\hline & Senna alata & 16 & 16 \\
\hline & Cynodon dactylon & - & 17 \\
\hline Total & & 36 & 70 \\
\hline
\end{tabular}

Weed species observed in the present study are common in the semi-arid region of Brazil (Linhares et al., 2009; Marques et al., 2011; Mesquita et al., 2017).
Other species (Ipomoea triloba, Blainvillea lanceolata) were also reported to be present in summer crops of this region (Silva et al., 2009; Silva et al., 2010).

The highest weeds dry matter was observed in 2017 for both cultivars (Figure 2). The higher weeds density was observed for BRS Seda compared to CNPA G2 in both years. The weeds density for BRS Seda in 2016 and 2017 were respectively 37 and 104 plants $\mathrm{m}^{-2}$, while for CNPA G2 was 36 and 70 plants $\mathrm{m}^{-2}$ (Table 2).

The higher weeds density in 2017 compared to 2016 for both cultivars may be related to higher rainfall intensity that occurred in 2017. In 2017, 486.5 $\mathrm{mm}$ of accumulated rain were recorded during 65 DAE, and this phenomenon did not happen in 2016. This fact allowed higher weed germination between the cultivation rows for both cultivars, increasing the plant density in 2017. In 2016, the weed germination between crop rows was lower due to no rainfall and irrigation system used. The drip system supply water only the crop rows (Wang; Li; Li, 2014). In the inter-rows, there is no water supply, reducing the germination of the weed in this area.

Plant height and leaf area for BRS Seda and CNPA G2 did not change in the year 2016 in plots with weed interference (Figure 3A and 3B). However, in the year 2017, the higher coexistence with weeds reduced the height and leaf area of the sesame cultivars (Figure 3C and 3D). In 2017, the higher density weeds in the between rows may reduce, mainly, the availability of mobile nutrients (McMurtrie; Näsholm, 2018), for the sesame cultivars due to the higher uptake by weeds through mass flow, increasing the interspecific competition between crop and weeds. This fact reflected in a lower height and foliar area of the cultivars in 2017.

\section{The critical period for weed control}

Relative yield data were analyzed separately for each year, and cultivar (Table 3 and Figure 4).

The increase in the period of weed interference reduced the relative yield of sesame cultivars in the years 2016 and 2017 (Figure 4).

The relative yield in plots with weed interference during 100 DAE was lower compared to weed-free for both cultivars. A reduction of 38 and $87 \%$ for BRS Seda and 54 and $84 \%$ for CNPA G2 was observed in the years 2016 and 2017 respectively (Figure 4). The lower reduction in the relative yield of grains in 2017 is a result of the higher weed density and dry matter that infested the area cultivated with BRS Seda and CNPA G2. The occurrence of rains in 2017 increased the incidence of weeds between 
crop rows. Consequently, this condition provided greater competition between the cultivars and weeds for water and nutrients, reducing grain yield.

The CPWC varied between the years and cultivars (Table 4). The CPWC of cultivars in 2017 was higher than in 2016 for all levels of losses considered (Table 4). The beginning of weed control for cultivars in 2016 and 2017 did not change (Table 4).
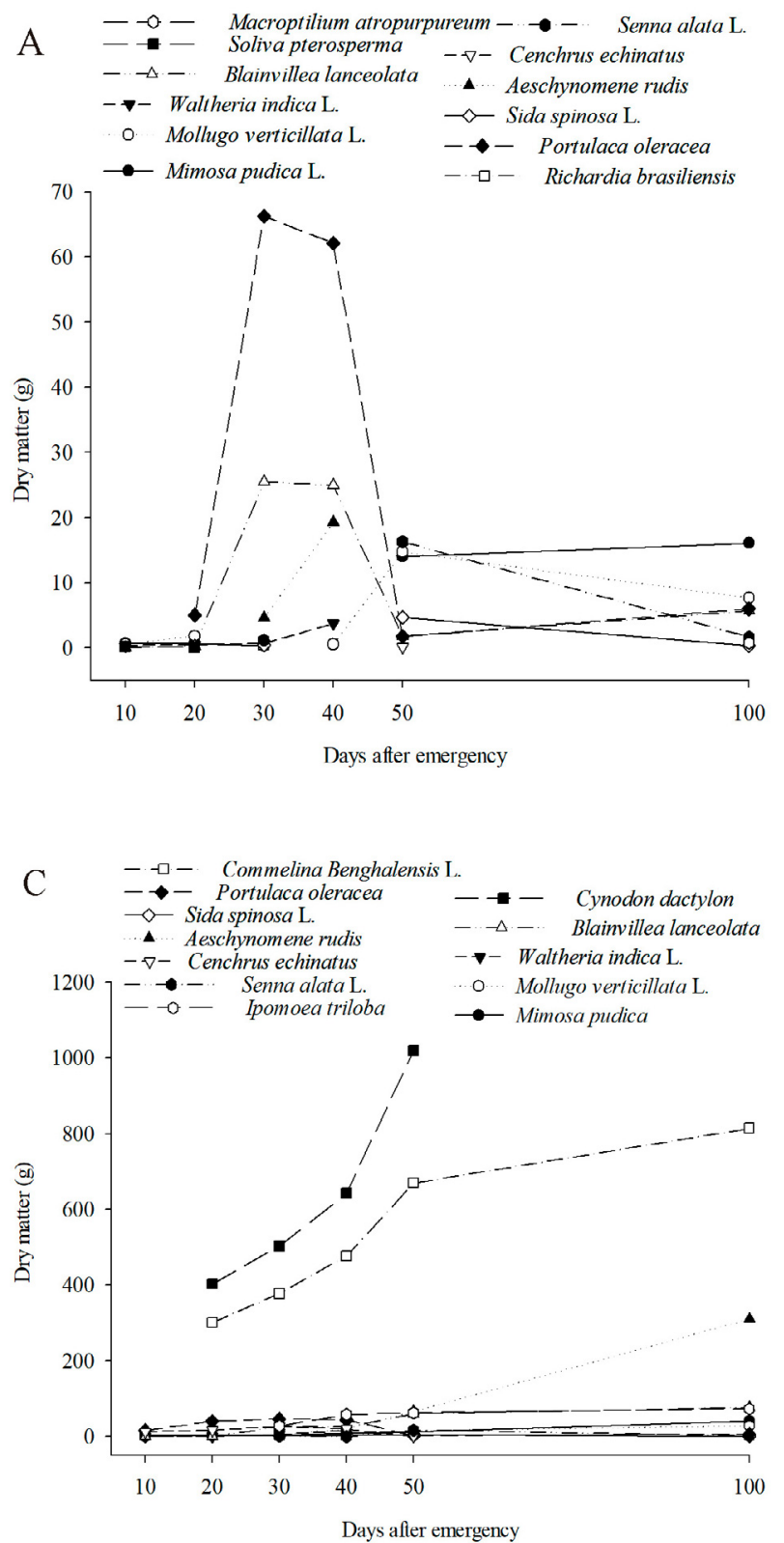

The small variation at the beginning of weed control may be related to the physiological characteristics of sesame. This crop has a low initial growth rate (Azevedo et al., 2007; Beltrão et al., 2006) which reduces the competitiveness and increases the sensitivity of sesame to weed interference in the initial periods, reflecting a smaller variation between the years 2016 and 2017.
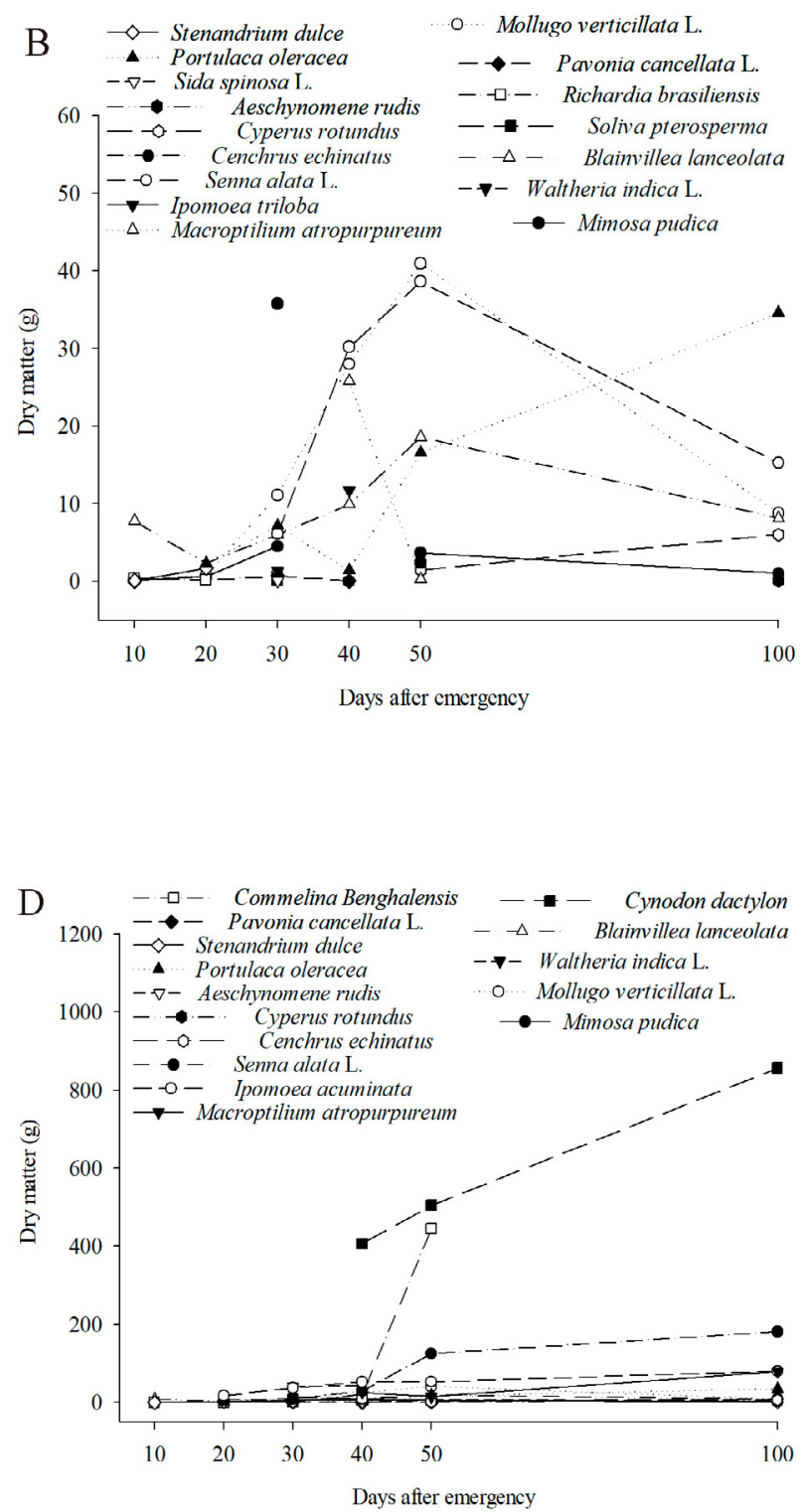

Figure 2: Dry matter of weeds in the area evaluated at $10,20,30,40,50$, and 100 DAE of sesame. $A=B R S$ Seda in 2016; B = CNPA G2 in 2016; C = BRS Seda in 2017; D = CNPA G2 in 2017. 

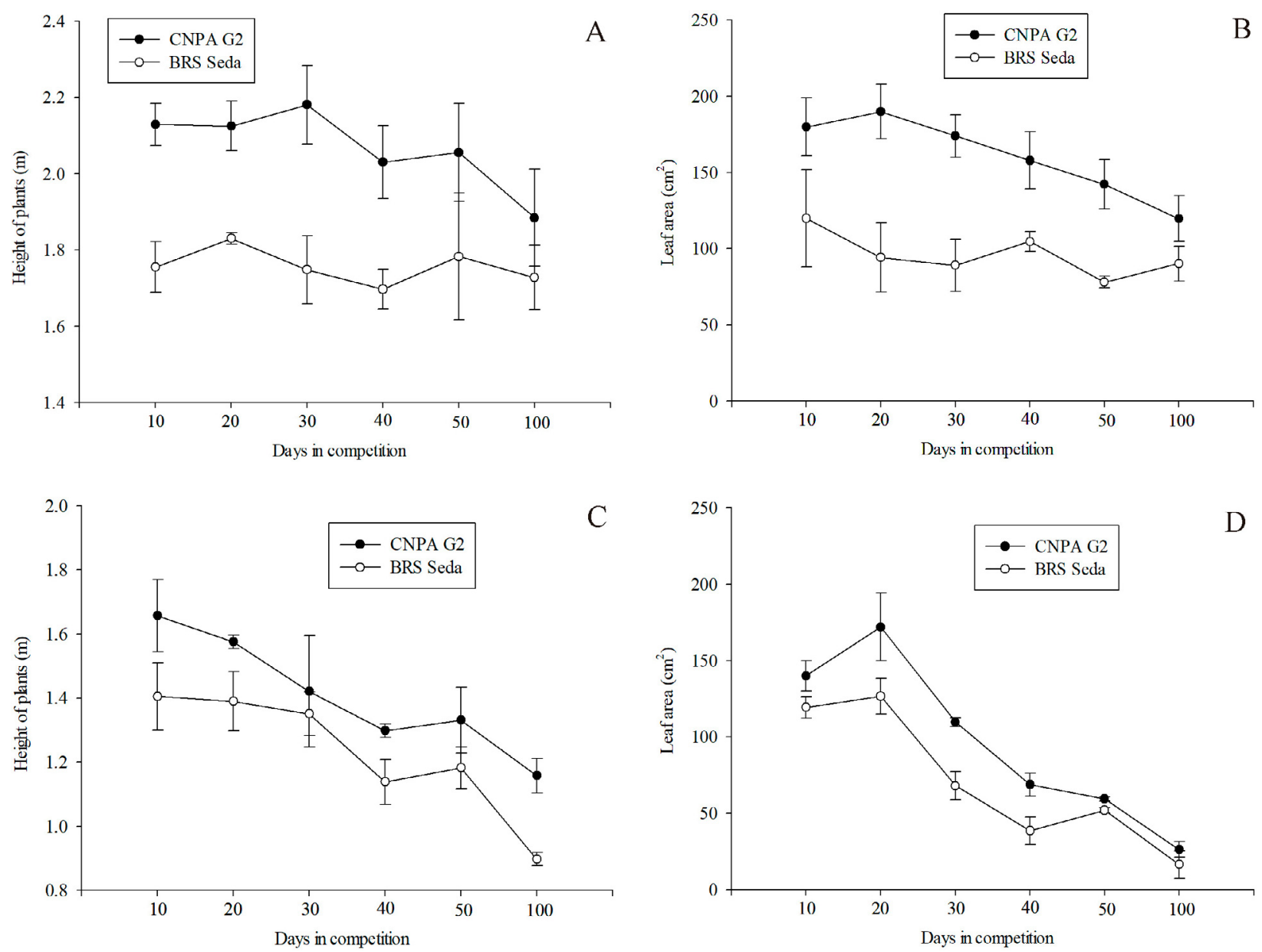

Figure 3: Height of plants and leaf area of sesame plants at 10, 20, 30, 40, 50, and $100 \mathrm{DAE}$, living with weeds present in the area, in the years 2016 (A; B) and 2017 (C; D). Bars indicate the standard error of the mean.

Table 3: Regression parameters characterizing the influence of weed interference duration on sesame yield of two cultivars for two production cycles.

\begin{tabular}{cccccccc}
\hline & & \multicolumn{6}{c}{ Regression Parameters } \\
\hline \multirow{2}{*}{ Year } & Grow crops & Curve & A & B & EC $_{50}$ & C & $\mathrm{r}^{2}$ \\
\hline \multirow{2}{*}{2016} & \multirow{2}{*}{ BRS Seda } & Weed-free & 14.8 & 130.12 & 35.21 & 1.05 & 0.99 \\
& & Weedy & 12.97 & 101.57 & 29.71 & -2.836 & 0.99 \\
\hline \multirow{2}{*}{2017} & \multirow{2}{*}{ BRS Seda } & Weed-free & 53.17 & 217.04 & 327.4 & 0.767 & 0.99 \\
& & Weedy & 61.9 & 101.58 & 16.88 & -4.33 & 0.96 \\
\hline \multirow{2}{*}{2016} & \multirow{2}{*}{ CNPA G2 } & Weed-free & 48.33 & 125.71 & 40.47 & 0.89 & 0.97 \\
& & Weedy & 50.51 & 100.17 & 23.1 & -6.98 & 0.98 \\
\hline \multirow{2}{*}{2017} & \multirow{2}{*}{ CNPA G2 } & Weed-free & 16.38 & 120.63 & 29.08 & 1.23 & 0.98 \\
& & Weedy & 11.72 & 101.6 & 39.64 & -3.06 & 0.99 \\
\hline
\end{tabular}

$A$ : slope of the line at the point of inflection; $C$ : lower limit; $B$ : upper limit; $E C 50$ : increasing graduation days giving a $50 \%$ response between upper and lower limit. $r^{2}$ : coefficient of determination. 
BRS Seda - 2016

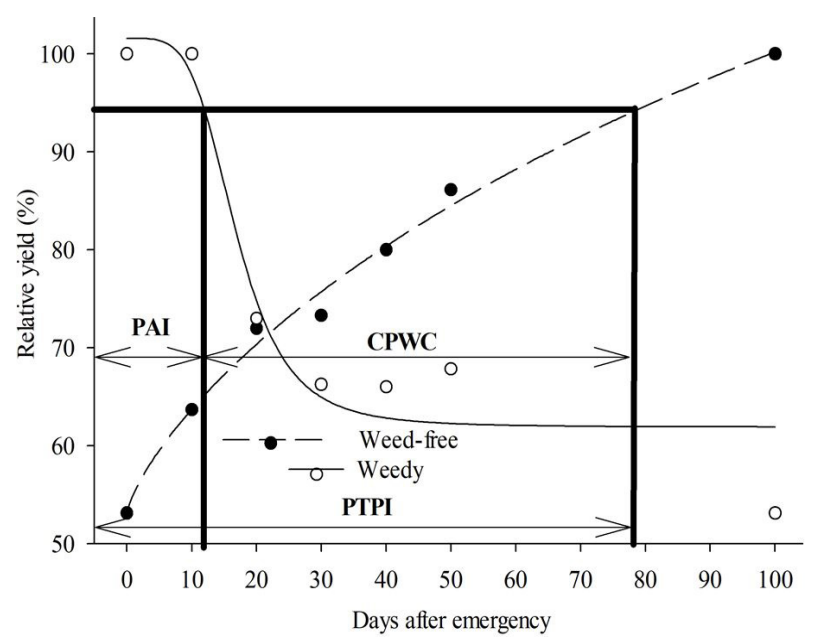

BRS Seda - 2017

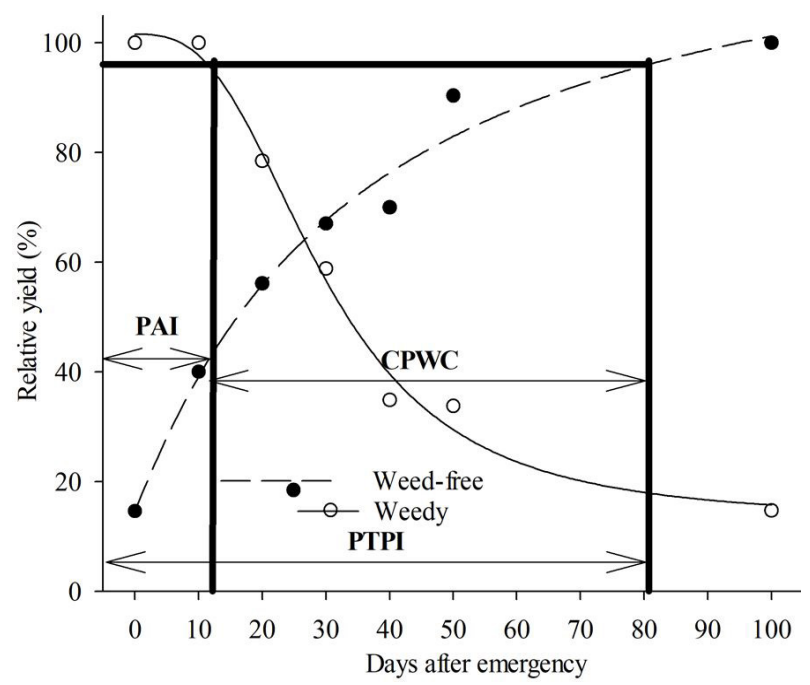

CNPA G2 - 2016

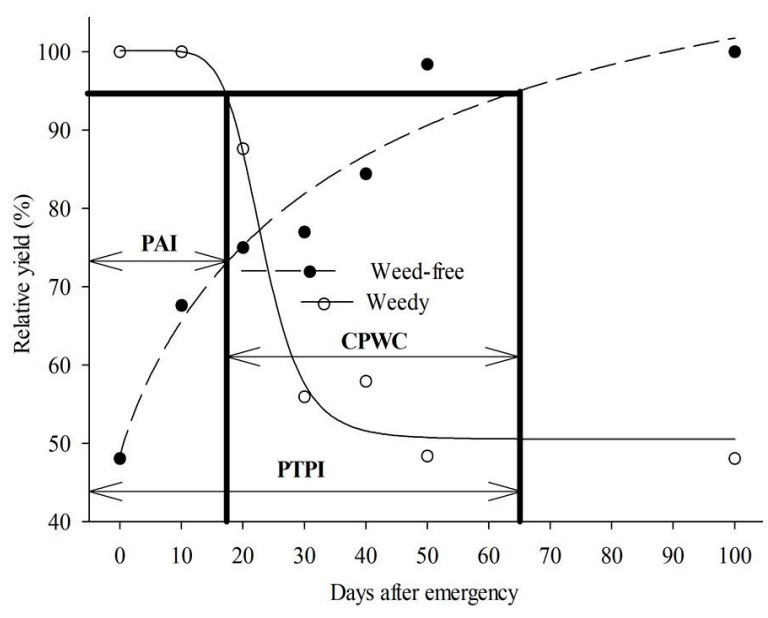

CNPA G2 - 2017

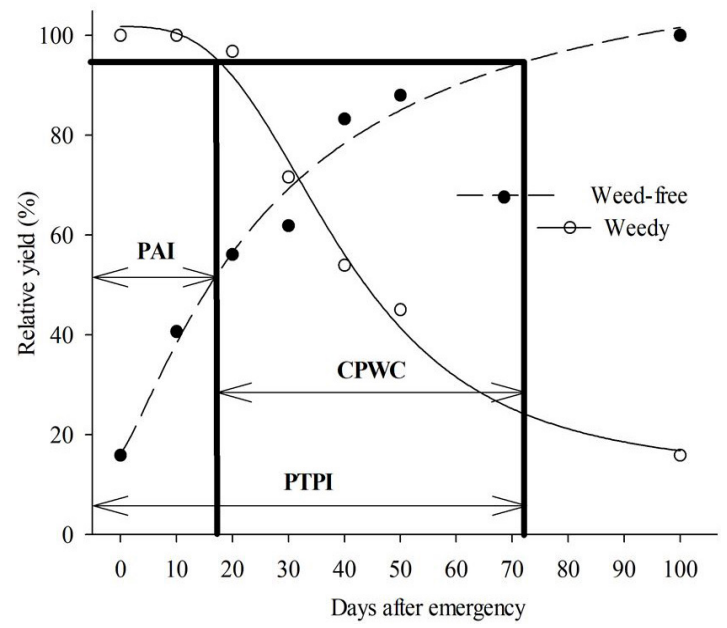

Figure 4: Pre-interference period polynomial regression (PAI), total interference prevention period (PTPI) and critical period of interference prevention (CPWC), tolerating at most a 5\% loss in relative productivity for two sesame cultivars. The regression lines are plotted using Equation 1, and the parameter values are presented in Table 3.

However, the end of control increased in 2017 , reflecting a higher CPWC in 2017 (Table 4). The observed rainfall in the range of 2 to 66 DAE of sesame in 2017 increased soil moisture between crops rows. The water supply during this period helped in the weed growth, increasing the weed biomass and density. This fact may have intensified competition between sesame cultivars and weeds. Therefore, during the 2017 season, control measures at the end of the cycle were necessary to ensure cultivars productivity.
The cultivar BRS Seda presented a higher CPWC than the CNPA G2 in the two evaluated years (Table 4). The difference between CPWC for cultivars, considering losses of 2.5 and $5 \%$, was 30 and $23 \%$ in the years 2016 and 2017, respectively (Table 4). Some characteristics of the CNPA G2 may increase the competitive capacity of this cultivar compared to the BRS Seda, resulting in a lower observed CPWC. The weed population can change when different species are grown in the same area. Some crops may have a higher competitive capacity with 
certain weed species than others (Tursun et al., 2016). In a study evaluating the CPWC of two sesame cultivars in irrigated systems, it was observed that weed density in areas cultivated with Oltan sesame was higher compared to Kalat landrace (Zarghani et al., 2017). According to these authors, the cultivar Kalat landrace was more competitive due to its higher precocity and the closing of the canopy to be faster than Oltan (difference of 20 days between cycles).

Table 4: Pre-Interference Period (PAl), Critical Interference Prevention Period (CPWC) and Total Interference Prevention Period (PTPI) for weed control in two sesame cultivars (BRS Seda and CNPA G2) in two years (2016 and 2017).

\begin{tabular}{cccccc}
\hline & & \multicolumn{4}{c}{ Interference Periods } \\
\hline Year & $\begin{array}{c}\text { Reduced } \\
\text { Productivity (\%) }\end{array}$ & $\begin{array}{c}\text { Grow } \\
\text { Crops }\end{array}$ & PAI* & CPWC & PTPI* \\
\hline \multirow{3}{*}{2016} & 5 & BRS Seda & 12 & 65 & 77 \\
& \multirow{2}{*}{10} & CNPA G2 & 17 & 48 & 65 \\
& & BRS Seda & 15 & 49 & 64 \\
& \multirow{2}{*}{2017} & CNPA G2 & 19 & 29 & 48 \\
\hline \multirow{3}{*}{} & \multirow{2}{*}{10} & BRS Seda & 12 & 69 & 81 \\
& & CNPA G2 & 17 & 55 & 72 \\
& & BRS Seda & 14 & 51 & 65 \\
& & CNPA G2 & 21 & 39 & 60 \\
\hline
\end{tabular}

* Days after emergency.

However, in this work, the higher competitive capacity of the CNPA G2 cultivar may be related to its greater size compared to the BRS Seda (Figure 3). Despite the morphological and physiological similarity of the sesame cultivars, small differences can make a particular cultivar more competitive (Biabani, 2015). The CNPA G2 cultivar had a higher leaf area and height than the BRS Seda in both years of cultivation (Figure 3A and 3B). Other studies also showed this difference between cultivars in field crops (Maciel, 2014). Thus, the amount of light available in the region below the canopy in CNPA G2 crops is lower than those grown with BRS Seda. The greater shading promoted by the CNPA G2 cultivar reduces the weed growth rate and, consequently, increases the competitive capacity of the weed. Thus, in cultivations with CNPA G2, the crop control promoted by the higher canopy closure reduces the CPWC compared to the cultivar BRS Seda.
The CPWC of the cultivar BRS Seda was 30 days longer compared to the CNPA G2 (Table 4). In conditions where acceptable losses are less rigorous, the CPWC is lower. However, the acceptable loss value must be defined according to the cost of control and the value added of the harvested product. Despite the more significant difference in CPWC for the CNPA G2 cultivar compared to the BRS Seda when considering a loss of $10 \%$, this value is very high, and generally losses of $10 \%$ represent losses to the producer, even in conditions where the cost with the control is high (Owen, 2015; Vasileiadis, 2015).

The results of this study will contribute to developing new alternatives that reduce costs and increase the efficiency of weed control. Understanding the weed behavior and the competitive capacity of each sesame cultivar is possible to establish strategies for integrated weed management, avoiding the adverse effects caused by competition (Amador-Ramirez, 2002). For example, the use of pre-emergence herbicides can mitigate the competition with weeds in a period where the sesame demonstrated high sensitivity to interference. Besides that, this practice can prolong the beginning of weed control and reduce the number of post-emergence applications in BRS Seda and CNPA G2 cultivars (Knezevic et al., 2002).

\section{CONCLUSIONS}

The cultivar CNPA G2 has a higher competitive capacity with weeds than BRS Seda. Weed control for the BRS Seda cultivar should begin between the 12 and 15 days, and for CNPA G2 between the 17 and 20 days, considering a loss of 5 and $10 \%$ respectively. The CPWC for BRS Seda is on average 67 and 52 days, and for CNPA G2 52 and 34 days, considering a loss of 5 and $10 \%$ respectively.

\section{ACKNOWLEDGEMENTS}

This study was financed in part by the Coordenação de Aperfeiçoamento de Pessoal de Nível Superior - Brasil (CAPES) - Finance Code 001, and to the research group at the Crop Science Department of the Universidade Federal Rural do Semi-Árido, which develops technologies for oleaginous crops on farms.

\section{REFERENCES}

AMADOR-RAMIREZ, M. D. Critical period of weed control in transplanted chili pepper. Weed Research, 42:203-209, 2002. 
AMARAL, J. A. B.; SILVA, M. T. Evapotranspiration and sesame crop coefficient for irrigation management. Brazilian Journal of Oleaginous and Fibrous, 12:25-33, 2008.

AZEVEDO, D. M. P. et al. Weed control. In: AZEVEDO, D. M. P.; BELTRÃO, N. E. M. (ed.). The agribusiness of castor bean in Brazil. Embrapa Algodão: Campina Grande, 2007. p.333-359.

BAHADOR, M.; MOOSAVI, S. G. A. Study on the effect of weeds interference periods and plant density of on some traits of sesame (Sesamum indicum L.) and weeds in Birjand. Iran Biological Forum - An International Journal, 7:16091615, 2015.

BELTRÃO, N. E. M. et al. The sustainable cultivation of castor bean in the Brazilian semi-arid region. Embrapa Algodão: Campina Grande, 2006, 62p.

BELTRÃO, N. E. M. et al. Sesame and its cultivation in the Brazilian semiarid. Editora IFRN: Natal, 2013. 254p.

BHADAURIA, N.; ARORA, A.; YADAV, K. S. Effect of weed management practices on seed yield and nutrient uptake in sesame. Indian Journal of Weed Science, 44(2):129131, 2012.

BIABANI, A. Evaluation of rice cultivars in weeds control different periods under non-stress and stress conditions. Russian Agricultural Sciences, 41(4):206-210, 2015.

CARMO FILHO, F.; ESPÍNOLA SOBRINHO, J.; MAIA NETO, J. M. Climatological data from Mossoró: A semi-arid northeastern municipality. ESAM: Mossoró, 1991. 121p.

CAVALCANTI, F.J. A. Fertilizer recommendations for the state of Pernambuco: $2^{a}$ aproximation. IPA: Recife, 2008, 212p.

CHAUHAN, B. S.; MAHAJAN, G. Recent advances in weed management. Springer: New York, 2014, 411p.

EMPRESA BRASILEIRA DE PESQUISA AGROPECUÁRIA EMBRAPA. Brazilian system of soil classification. 5th edition. Embrapa Solos: Brasília, 2018. 531p.

FURTADO, G. F. et al. Weed interference periods in sunflower crop. Revista Verde de Agroecologia e Desenvolvimento Sustentável, 7:12-17. 2012.

GRILO JR, J. A. S.; AZEVEDO, P. V. Growth, development and productivity of sesame BRS Seda in agrovila de Canudos, em Ceará Mirim (RN). Holos, 29:19-33, 2013.

KNEZEVIC, S. Z. et al. Critical period for weed control: The concept and data analysis. Weed Science, 50:773-786, 2002.
KNEZEVIC, S. Z.; STREIBIG, J. C.; RITZ, C. Utilizing R software package for dose-response studies: The concept and data analysis. Weed Technology, 21:840-848, 2007.

LINHARES, E. L. R. et al. Planting density of gliricidia when intercropped with corn for weed control. Planta Daninha, 27:967-975, 2009.

MACIEL, D. Periods of weed interference in chicory cultivars development in indirect sowing system. Journal of Food, Agriculture \& Environment, 12:1296-1299, 2014.

MAHGOUB, B. M.; OMER, S. O.; ELAMIN, S. A. The critical period of weed control in sesame (Sesamum orientale L.). Journal of Forest Products and Industries, 3:66-70, 2014.

MANE, S. V. Weed Management in Sesame (Sesamum indicum L.) grown under Coastal Region of Maharashtra. Journal of the Indian Society of Coastal Agricultural Research, 35:31-33, 2017.

MARQUES, L. J. P. et al. Population dynamics and weed phytosociology in the cultivation of cowpea and cassava in the cutting and burning system with the use of plow. Planta Daninha, 29:981-989, 2011.

MCMURTRIE, R. E.; NÄSHOLM, T. Quantifying the contribution of mass flow to nitrogen acquisition by an individual plant root. New Phytologist, 218:119-130, 2018.

MESQUITA, H. C. et al. Effectiveness and selectivity of herbicides in cowpea cultivars. Revista Brasileira de Herbicidas, 16:50-59, 2017.

OWEN, M. D. K. Integrated pest management and weed management in the United States and Canada. Pest Management Science, 71:357-376, 2015.

SILVA, L. C. et al. Simple method to estimate leaf area of sesame plants (Sesamum indicum L.). Brazilian Journal of Oilseeds and Fibrous, 6:491-495, 2002.

SILVA, P. S. L. et al. Growth and yield of corn grain and green ear in competition with weeds. Planta Daninha, 27:947955, 2009.

SILVA, P. S. L. et al. Effects of weed "reestablishment" after hoeing on corn yields. Planta Daninha, 28:281-291, 2010.

SINGH, M.; BHULLAR, M. S.; CHAUHAN, B. S. The critical period for weed control in dry-seeded rice. Crop Protection, 66:80-85, 2014.

SWANTON, C. J.; NKOA, R.; BLACKSHAW, R. E. Experimental methods for crop-weed competition studies. Weed Science, 63:2-11, 2015. 
TURSUN, N. et al. Row spacing impacts the critical period for weed control in cotton (Gossypium hirsutum). Phytoparasitica, 44:139-149, 2016.

VASILEIADIS, V. P. On-farm evaluation of integrated weed management tools for maize production in three different agro-environments in Europe: Agronomic efficacy, herbicide use reduction, and economic sustainability. European Journal of Agronomy, 63:71-78, 2015.
WANG, Z.; LI, J.; LI, Y. Effects of drip irrigation system uniformity and nitrogen applied on deep percolation and nitrate leaching during growing seasons of spring maize in semihumid region. Irrigation Science, 32:221-236, 2014.

ZARGHANI, H. et al. Determination of critical period of weeds control in sesame (Sesamum indicum L.) in mashhad condition. Iranian Journal of Field Crops Research, 15:231-243, 2017. 